\title{
The Role of Higher Education in Social Transformation and Rural Development
}

\author{
Loyiso M. Luvalo
}

\author{
Department of Educational Foundations, University of South Africa
}

luvallm@unisa.ac.za

\section{Doi:10.5901/mjss.2014.v5n23p1206}

\begin{abstract}
Responding to pressures brought about by globalization, the restructuring of higher education internationally and in South Africa over the past ten years has meant that universities have to play a critical role in social transformation. Adding to this also was a slow pace of economic development in communities which universities exists has led the government to challenge Higher Education(HE) to partake in the process of socio-economic development, especially in rural areas. The contesting views on what role higher education play in this process stems from the historical role that HE played in South Africa and in the world generally. This article asserts that besides teaching and research, institutions of higher learning have an important role to play in the process of changing lives of the people in the rural areas. Universities have frequently been regarded as key institutions in the process of social change and development. The most explicit role they have been allocated is the production of highly skilled labour and research output to meet the perceived needs of economy (Brennan, 2004). The roles played by universities in the modernization projects vary. According to Clark, (1998) \& King (2004) it is important to distinguish between examples where the role of the university is largely autonomous and examples where the role is set firmly within state plans and control mechanism. The findings of the study are based on the qualitative research conducted at two rural universities in South Africa that have established Centers for Rural Development, which are responsible for projects that are contributing to rural development.
\end{abstract}

Keywords: Higher education, transformation, rural development, society

\section{Introduction}

This paper seeks to contribute to the contemporary debate about the role that higher education can play in addressing poor living conditions especially in the local areas where some South African universities are located. The paper is premised on the notion that the government cannot work independently of other organisations, such as universities, in pursuit of social transformation in South Africa. In addition, universities have inherent resources, human and materialistic, which if adequately utilize and shared with local communities, can play a significant role in social transformation and development of rural communities.

The paper is composed of four sections. In the next section presents the background of the research from which the paper draws. Next is the review of literature related to higher education and its role in rural development and social transformation? In the third section, methodology that was used during data collection is presented. This is followed by presentation and discussion of findings. Lastly the conclusion will be presented.

\section{Background}

In response to the changing economic markets and pressures brought about by globalization, the restructuring of higher education in South Africa over the past ten years (in which South Africa became a democratic country) has meant that universities have to play a critical role in social transformation. The slow pace of economic development in areas which universities exists has led the government to challenge Higher Education(HE) to partake in the process of socioeconomic development, especially in rural areas. The contesting views on what role higher education plays in this process stems from the historical role that HE played in South Africa and in the world generally. Universities have frequently been regarded as key institutions in the process of social change and development. The most explicit role they have been allocated is the production of highly skilled labour and research output to meet the perceived needs of economy Brennan, (2004). In South Africa universities in the democratic dispensation have to firstly contribute towards economic and socio-political transformation, secondly they are expected to serve public good and produce critical citizens for vibrant democratic society. Lastly, universities are considered as intrinsic sites of civil society, and then the focus on 
the relationship between the state and civil society can be used to better illuminate some of the problems associated with the role of universities in the post-apartheid system, Reddy (1994). According to Clark, (1998) \& King (2004) it is important to distinguish between examples where the role of the university is largely autonomous and examples where the role is set firmly within state plans and control mechanism. There is still ambiguity in the literature when it comes to the very definition of social transformation itself. The issues of how and what must be transformed, always come up whenever the issue of social transformation is discussed in literature. Reddy(2004) describes social transformation as a complex process which is informed by processes like change in political ideas that lead to economic change and socialization of people and transmission of knowledge, skills culture and values.

Another important point is that in rural communities of South Africa, there is a high rate of illiteracy. Therefore, rural people need to acquire new skills, new attitudes and new technology. Rural communities should be developed so that they can realize and experience that to have a good quality of life does not necessarily mean access to jobs in urban areas, which generally results in the exodus of rural people to cities like Johannesburg, Durban and Cape Town, in case of South Africa. People in the rural areas must be helped to have potential for their self-sustenance. This massive movement of people from rural to urban areas is driven by need for employment and seeking better living conditions, sometimes this leading to crime involvement and family disintegration. These points to the reality that lives of people in rural areas needs to be improved and institutions of higher education can play an important role in this regard, Maminza, (2009).

Research on the current role that higher education plays in socio-economic development could help change the view that rural development is only a responsibility of those universities in the rural areas. Jansen (2003) argues that in all countries that have undergone political changes towards the end of 1990's like Eastern Europe and South Africa, the role of higher education has been linked to the view point of economic and social transformation. Therefore universities, irrespective of where they are situated, are expected to be able to supply the country with new labour force to be at par with other developing countries and the rest of the world.

Walter Sisulu University (WSU) in the Eastern Cape and University of Limpopo in Limpopo Provinces of South Africa, have established Centers for Rural Development, which are responsible for projects that are contributing to rural development. In order to contribute to the debate about higher education and rural development, this study presents the view that institutions of higher learning are involved in the process of changing lives of the people in the rural areas. King\& Lebeau (2004) argue that when one is looking at universities and social transformation, it is important to distinguish between universities that ignite change, those that accelerate existing change and those that block change. On the basis of this view the two above mentioned institutions were selected as they are perceived to be accelerating change and development in their rural setting. It is also hoped that the findings in this study will prompt those well-resourced institutions of higher education in the urban areas to take part in rural development.

\section{Literature Review}

In this section the paper presents conceptual understanding of social transformation and university's role in rural development.

In an attempt to explore possible meaning of the above, I draw on the philosophy of Brennan \& Lebeau, (2004:2). "Social transformation lies at the radical end of conceptions of social change. It implies at the very least some fundamental changes in society's core institution, the polity and the economy, with major implications for relationships between social groups or classes, and for the means of the creation and distribution of wealth power and status." Brennan \& Lebeau, (2002:2). This implies that in case of South Africa the fall of apartheid regime led to social change and the universities had to change the way they operated and became more responsive to the need of the society.

Social transformation concept in South African context became more eminent during a turbulent period especially from 1990 leading up to first democratic election of 1994. This period was characterized by disillusionment, critique and repression by the old regime which was the Nationalist Party (the pre-1994 ruling party). Another phase of social change was the post 1994 elections, when the building of the new South Africa started. This phase was said to be of reconstruction, institution building, forming new social relationships, alliances at home and abroad and attempt on economic regeneration and redistribution. This is usually the period of uncertainty because of its length, dramatic changes of transformation that will gradually merge into more revolutionary processes.

Although there are numerous definitions of a university, in the context of this paper it is referred to an institution of higher learning where one can be equipped with skills and knowledge that will help in the working world. Saltmarsh (2009:65) emphasizes Dewey's emphasis on "higher education as an instrument for transformation so as not to perpetuate un-democratic education and un-democratic society." Because of this definition, and the fact that universities 
operates among different societies, higher education is expected to be sensitive to ideals of what it should be for. According to Robertson and Allen (1997) higher education must be fundamentally committed to social justice and accept that the pursuit of social justice is an arm of national effectiveness. For this to happen, higher education institutions will need to be modernized culturally, organizationally and politically. However in recent times, the "modernization" of a university has adopted a corporate culture leading to reduction of programs for community development. Full transformation can best be realized within the context of a learning society in which participation in higher education becomes a natural part of the learning careers of most individuals. In a learning society which features universities as major assets, most people would enter higher education for some purpose at some time in their lives to gain reputable credentials for personal advancement, either in employment or more generally. When universities present themselves as public assets in this manner, it is more likely that they will be able to assemble coalitions of popular support for a longterm security and prosperity. This argument validates the fact that once universities are perceived to be part of the society they exist in, in terms of changing people's social status, they contribute to transformation of society. What can also be added to this role of universities is that especially during periods of more radical change, roles in the building of new institutions of civil society, in encouraging and facilitating new cultural values, and in training and socializing members of new social elites.

For the purpose of this study, it is important to understand the previous role of higher education in South Africa both before and after apartheid period.

\section{South African Higher Education before 1994}

For the longest time higher education in South Africa was part of the separatist state's ideology of apartheid. As already indicated in the introduction even though later black universities were later established, they were merely structures with no contribution at all at making black graduate economically active. Because of this, black universities became battle grounds for fight against apartheid especially in the 1980's. This is briefly referred to by Reddy (2004) that the spread of Black Consciousness beyond a small group of university students, and the experience of 1972 boycotts contributed towards a rejection of Apartheid education in most urban areas. At about the same time as the resurgence in the student movement, black workers increasingly went on strike demanding wage increases, union recognition, and improved working conditions. The watershed event that changed the terrain of labour relations was the "spontaneous" strike wave during 1973.

The Nationalist Party government put in place constraints to prevent institutions designed for the use of one race group from enrolling students from another race group. According to Bunting, (1997) "higher education was skewed in ways designed to entrench the power and privilege of the ruling white minority". (p.52)this is concurred to by Badat et al (1994) that with its racially and ethnically defined institutions and its racial distribution of students across particular fields and levels of study, the higher education system itself served to contrast and maintain the social ,political and economic features of the apartheid order. By 1994, the landscape of 36 higher education institutions included ten historically disadvantaged universities and seven historically disadvantaged technikons (type of college or university that teaches mainly practical subjects) designed for the use of black (African, coloured and Indian) South Africans, while ten historically advantaged universities and seven historically advantaged technikons were designed for the exclusive development of white South Africans. Two distance learning institutions i.e. the University of South Africa and Vista University catered for all races.

There had been a considerable resistance by 1994 to the apartheid regime in the historically black and some of the historically white institutions and, as alluded to earlier, the racial profile of student enrolments in some of the institutions had departed considerably from apartheid's intentions. It was in this context that the new higher education policies of South Africa's first and second democratic governments sought to reshape the system into one that met the goals of equity, demonstration, responsiveness and efficiency.

\section{Post 1994 Higher Education}

The South Africa government was faced with the task of transforming Higher Education (HE) from its racialised past to the one suitable for democratic society. According to Reddy (2004) these determined efforts to restructure HE are best understood in relation to the type of transition from apartheid, the macro economic framework set out by the African National Congress(ANC) government and the nature of state-civil society through which the government wanted to change inherited past social relations. 
Policy in Higher Education was guided by a government's structure called the National Qualifications Framework (NQF), which came into being as the result of National Commission on Higher Education (NHC). This commission was set by the then minister of education in 1995 to look into transformation of higher education that is how merger of a number of institutions of higher learning came about. The NHC recommended that "higher education can play a pivotal role in the political, economic and cultural reconstruction and development of South Africa" (p1). This meant that higher education would have an immense contribution in social transformation in the country. As mentioned earlier, in the previous regime, universities were acting as "autonomous entities "only focusing on teaching and research. However, the new role of responding to social needs came with its challenges.

Post-apartheid higher education has to deal with number of issues such as rural development, access to higher education, curriculum changes e.g. what gets taught and researched, human resource management. In a nutshell higher education in South Africa has been bogged into the crucial role of economic, social and political transformation. Following is the brief discussion of development and its significance to the rural communities.

\section{Development and Its Significance to Rural Communities}

According to Delahunty, Hawkins and McDonald (1998) the noun "development" is derived from the verb 'to develop', which means to cause grow larger, fuller or more mature. According to this definition development has to do with growth in, among others, knowledge and skills (Gamble, 2003). Gego (1998) defines development as a process of growth springing from within, which involves a growing individual and collective self-reliance, and focuses not only on material and economic needs, but also on emotional, ethical and political empowerment. This view is further supported by Nel, Hill and Binns (1997) who state that the development is not about the delivery of goods to a passive citizenry, but it is about active involvement and growing empowerment. The empowerment implies the development of skills to enable them to cross of working with individuals or organizations to enable them to cross a threshold, which has qualitative importance to them and their lives. Development is about empowering people to perform a set of task at a high standard, where standards are measure by their appropriateness for a specific and yet dynamic social or economic purpose. The involvement of the local rural communities, who are targeted by development initiatives, is emphasized by Gego (1998) who suggests that local communities ought to participate in development initiatives that target them. It is therefore necessary for rural community members to have the basic requirements for participation, namely literacy and numeracy skills. The Presidential Integrated Sustainable Rural Development Strategy (South Africa, 2000b) refers to rural development as a dimensional concept that focuses not only on poverty alleviation, but also on the change of rural environments. This indicates that the crucial role of training in development, particularly rural development. The role of development to uplift rural communities cannot be overemphasized. It is of critical importance that development programmes and/or projects are developed, packed and sourced to rural communities. Higher education and other development agents need to take this responsibility very seriously in order to assist rural communities.

\section{Methodology}

Qualitative methods were used in this paper in investigating the role of institutions of higher learning in socio-economic transformation and rural development. This is the case-study of two institutions of higher learning, conducted at the Centre for Rural Development at Walter Sisulu University, in the Eastern Cape and University of Limpopo; in Limpopo Province, South Africa. Research tools for data gathering are mixed in order to widen the scope of gathered data, Cohen and Manion (2000). Use of mixed methods in a research has led to "demystifying" the fact that the two cannot be mixed in a qualitative study or quantitative, Brunner (2008). Cohen and Manion (2000:189) also argue that, the use of "multiple resources "in terms of data collection allows the researcher to give descriptions of the narratives of the methodological process accomplished during the investigation. Questionnaires with open ended questions were designed and interviews were conducted. The sample consists of individuals from each Centre for Rural Development of both institutions. The respondents vary according to seniority in their positions. Two members of each rural development projects leaders were interviewed. The respondents were selected across the spectrum of the stake holders involved in the rural development programs, so as to gather a more representative data.

As mentioned in the introductory part of the study, the two institutions are selected because they are both based in rural areas and they embarked on projects that aimed at contributing to socio-economic change of the people. Following is the discussion of the findings. 


\section{Findings and Discussion}

Resulting from the questions that formed the basis of interviews for the study the following aspects related to the role of the two institutions in social transformation and rural developments were apparent: the global economic changes, capacity building for community development and rural co-operative enterprises, provision of work-integrated learning opportunities within community settings, multi stake holder participation and sustaining of projects. These will be each discussed below.

\subsection{Changes in global economies and HE in South Africa}

From the question focused on the reasons behind establishment of centers for rural development in both universities, it was apparent that political changes that took place in global economies in the early 1990's brought pressures that led to the collapse of apartheid system in South Africa and the restructuring of higher education. Higher Education in a democratic, on-racist and non-sexist South Africa had to:

a) Accept the responsibility for directing their teaching and research towards strengthening of communities and their capacities to empower themselves. (b) Play a critical role in identifying and addressing significant social problems. (c)generate new knowledge towards solving educational, housing and economic problems of needy communities and(d)to be seen playing a major role in ensuring the development of a more just and equal society Higgs (2002). These had drastic influence in the establishment of the centers in these two universities. A participant confirmed this in his direct words: "our university could no longer just take students from these poor communities without giving anything back in terms of poverty alleviation projects" this concurs with (Reddy's, 2004) argument that in South African higher education it could not be business as usual, institutions in the rural communities felt that something had to be done to "address inherited inequalities, inefficiencies, faced up to new socio-economic and cultural challenges" (p.24). Community based projects had to be initiated to bring about relief to economically deprived communities.

\subsection{Capacity building for rural community co-operation}

There seems to have been a need for the universities in helping the communities in terms of knowledge skills in the project that they had started with other stake-holders. This is how the participant confirmed this:

"As a School of Agriculture we had various request from many communities that we need to assist on developmental issues. They wrote letters or just came down to discuss with the school but they were referred to the Agricultural Extension Department..."

Centers for Rural and Community development at these institutions serves a facilitators in terms of using the knowledge that they have in for an example agrarian production. Participant in the community project concurs with this view that involvement of staff members from School of Agriculture helped them with skills on agrarian production. Direct words of a participant in this regard are "for us to rear chicken and manufacturing of dairy product and marketing all of this was not possible until we attended workshops run by the university in our community". This was done in conjunction with various departments at the university, in one institution the department of Agriculture was at the forefront because of its expertise when it comes to farming. It came out that the center conducted workshops with the community and some government departments about the projects.

\subsection{Provision of work-integrated learning opportunities within community settings}

The focus here was on the universities' eventual objectives and skills they were focusing on in the community, especially among the youth.

The centers for rural development in both institutions have selected two or three students from the participating departments and learners from the local schools to work with the communities in the project. During an interview, a respondent in his direct words stated that "We said there are schools in the village and how can we get the schools involved? We wanted to curb the problem of the students not wanting to be involved in Agriculture, and then schools will have Drop-In Centres. These were catering for student-learners with in the communities, most of the learners are orphans and they go to these centres for food, although the government provides food in schools. Now we had 2 initial groups of dairy goats and chicken and we asked if they can't provide milk to the drop-in centres for orphans, the same 
with the chicken that students were experimenting with, the left-over's were sent to the drop-inn centres"

The above statement repudiates the notion that young people are not interested in agriculture as a career. The project's focus here was production of dairy goat products, which became very successful and there was chicken rearing, then it was decided that university students and learners would feed some of the children from orphanages with the products from the projects. The students were drawn from faculties of agricultural science and social work and community services. Students got training for their future careers and they also run tests on the feed for animals and poultry. Two roles in this instance that the project from the university plays (a) it becomes a source of food for the orphanages and (b) provides an opportunity for young people in the community to give back and harness their farming skills. The students also get to know more about what is involved in agriculture so that they can decide to take it further as a career.

\subsection{Stakeholder participation and sustainability of the projects.}

Here according to the interviews the two universities involved the community from the initial stages of the projects aiming at empowerment and development. Depending on the type of a project, for an example they involved the department of Land and Agriculture for Farming, department of Water Affairs and Health for irrigation and water boreholes. These departments were involved in order to deal with issues of water quality, usage and environment protection. The local municipality was also approached for use of the local hall for community forums, discussing the proposed projects and the value of it in their lives. This was confirmed by the respondents in this way:

"From the beginning, in fact here we say "we don't come with developmental issues. We can only identify problems, some innovation but who owns the whole process is the community. Then if that's the case, how do they bring it you? They do that at the Developmental Forum discussions or meetings. Then the developmental forum will highlight it. Unfortunately at the present moment we don't have Site Officers, we've lost one (he passed away and one got a job elsewhere) Then the Community Forums will always be represented by a Site officer identified by the Developmental Forum, 3 or 4 people from their communities, then we interview them. After that the successful, one's will work for the University, we as the university and the community will see that person as member of both the university and the community. So if there are concerns or innovations raised in the community, the person will know that will be supported by both the university, department of agriculture and community. For problem solving the person will need, .e.g. funding for project and this takes time for an action research, it's a process not just an event. So whatever problems or innovation that crop up, they will be taken to that particular person representing the university, attending the meetings both at the university and in the village. We make sure that we always have that link between the university and the community."

On the question of how the projects are sustained the response from the member of the community was that they are trained on areas like conducting a meeting, securing funding and book-keeping. This enables them to function even if the members of the university are no longer part of the projects. The challenge expressed by both university and community is that most of trained young people usually get employment elsewhere (as indicated in the statement above). To try and solve this both institutions have decided to do training at a large scale, so that they are left with people to continue with the projects.

\section{Conclusion}

The paper has discussed the role of higher education in social transformational and rural development. It has used the case study of the two universities (Walter Sisulu University and University of Limpopo) in South Africa. Specifically it has looked at how these institutions of higher learning through their centers specifically created for rural development have managed to empower and develop rural communities. The study makes the following conclusions: First the global economic changes that came with stringent policies changed the way universities used to operate because of hardships experienced by communities in their vicinities. Secondly higher education has a pivotal role to play in social transformation and some institutions are proving that with their rural development projects. This is possible because of the advantage of universities in terms of community project skills and human resources. Thirdly, consultation of the community is very important in all the stages of the projects aiming at making its lives better. Constant training on a large scale of the people involved in the projects helps in terms of project sustainability, which has led to the failure of many projects of this nature. Lastly the study addressed the void regarding the role that can be played by universities in development of rural communities, even if they are not well resourced. 


\section{References}

Badat, S., Barron, G.Fischer, P.Pillay, and H.Wolpe, Differentiation and Disadvantage: The Historically Black Universities in South Africa. Report to the Desmond Tutu Educational Trust. Education Policy Unite, Bellville, 1994.

Brennan, J. The Social Role of the Contemporary University: Contradictions, Boundaries and Change. Ten Years On: Changing Education in a Changing World, Centre for Higher Education Research and Information (CHERI). Buckingham: The Open University Press, 2004.

Brennan, J., Smith, and Y. Lebeau, The Role of the Universities in the Transformation of societies, Open University, London, 2004

Clark, B.R. Creating Enterpreneual Universities: Organizational Pathways of Transformation, Pergamon, Oxford, 1998.

Cohen, I. and Manion, L. Research Methods in Education, Routledge Farmer, London, 1994.

Delahunty, A., Hawkins, J.M. \& McDonald, F. 1998. The Mini Oxford School Dictionary. Oxford: Oxford University Press.

Gegeo, D.W. 1998. Indigenous knowledge and empowerment: Rural Development examined from within. The Contemporary Pacific. 10 (2): 289

Higgs, P., 2002. Nation building and the role of the university: A critical reflection. South African Journal for Higher Education. 16(2): 1117.

King, R. The University in the Global Age. Palgrave, London, 2004.

Maminza, P.M., The role of the University of South in the Development of Human Resources in Mpumalanga Province. Stellenbosch University Dissertation, Cape Town, 2009.

Nel, E., Hill, T. \& Binns, T. 1997. Development from below in the „new" South Africa: the case of Hertzog, Eastern Cape. The Geographical Journal. 163 (1): 58.

Reddy, T. Higher Education and Social Transformation: University of Cape Town, Cape Town, 2004.

Robertson. \& Allen, A. Young Applicant's Perception of Higher Education, Heist, Leeds, 1997.

Saltmarsh, S., Why Dewy Matters. The Good Society, Pennsylvanian State University, University Park, 2009, (17) 2, pp.63-4.

South Africa., 2008. Towards an Antipoverty Strategy for South Africa: A Discussion Document. Pretoria: Government Printers. 